\title{
Labor Market Outcomes of Informal Care Provision in Japan*
}

\author{
April 4, 2014
}

\section{Hiroyuki Yamada ${ }^{\dagger}$}

Associate Professor, Osaka School of International Public Policy (OSIPP)

\section{Satoshi Shimizutani ${ }^{\dagger \dagger}$}

Research Fellow, Research Division, Gender Equality Bureau, Cabinet Office

【Keywords】Informal care, Caregiver, Long-term care insurance, Labor supply, Japan

【JEL Classification Codes】 J22, I11

【Abstract】This paper examines the labor supply outcomes of family care provision for Japanese households in 2010, ten years after the introduction of the public long-term care insurance (LTCI) program. We found that family care provision for parents adversely affected labor market outcomes of main caregivers at home in terms of probability of working, employment status and hours worked. The adverse effect was found to be more serious for female caregivers than for male caregivers. Moreover, our results suggest that the public LTCI program seems to only partially mitigate the disadvantages of the main caregivers for both males and females.

* We are grateful to the Ministry of Health, Labour and Welfare for providing us with micro-data from the Comprehensive Survey of Living Conditions. The views expressed in this paper are completely personal and unrelated to those of the Japanese Government.

† corresponding author: E-mail: hyamada@osipp.osaka-u.ac.jp.

†† E-mail: satoshi.shimizutani@cao.go.jp. 


\section{Introduction}

An aging population is a common phenomenon among developed countries as well as some emerging countries especially in Asia. Together with extending longevity, care provision for the rapidly expanding population of frail elderly is one of the most serious challenges in the public policy arena. Since care provision at home has been conventionally borne mostly by women, dramatic demographic change may place more emphasis on women's role as caregivers, even though the capacity of family care provision has been diminishing under the prevalence of nuclear families. At the same time, most of those countries suffer from lower birth rates and expect their labor force to shrink in future. Thus, many countries are targeting females of prime age to participate in the labor force to compensate for the possible adverse effect of the shrining labor force on the economy. These countries are confronted with the dilemma of expecting women to be responsible both as caregivers and workers.

Japan is one of the countries that are most seriously challenged by this dilemma since it has been experiencing an unprecedented increase in the aging population and a historically stagnant birth rate. One solution to meet those seemingly contradictory policy requirements was to introduce the public long-term care insurance (LTCI) program, which occurred in 2000 , striving to "establish a system that responds to society's major concerns about aging, the care problem, whereby citizens can be 
assured that they will receive care and be supported by society as a whole" by shifting the responsibility of care from the family to the government (MHLW, 2002).

This paper provides new evidence on labor market outcomes of care provision in Japan. To do so, it examines the labor supply effect of family care provision for Japanese households in 2010, ten years after the introduction of the public long-term care insurance program. While many studies have examined the causal relationship between care provision and work using a variety of datasets, no consensus has formed on the presence and size of the adverse effect on labor market attachment. ${ }^{1}$ Moreover, our evidence on Japan's experience is informative for not only Japan, but also other countries because Japan is one of a few countries that have introduced a social insurance-type public LTCI program. ${ }^{2}$

The adverse effect may be expected to be naturally curtailed because the public LTCI program should substitute a part of family care provision but there is scarce

\footnotetext{
1 Van Houtven, et al. (2013) provides a decent and concise literature review. The literature analyzing the relationship between caregiving and work is quite extensive but the results are still mixed. While a negative relationship between family care provision and extensive margin of work in terms of work probability is found in most studies (e.g., Heitmueller (2007), Bolin, et al. (2008)), there is less consensus on intensive margins in terms of working hours (affirmative by Ettner (1996) for the U.S. and negative by Bolin, et al. (2008), Casado-Marín, et al. (2011) and Wolf and Soldo (1994) or in terms of wage penalties (affirmative by Carmichael and Charles (2003) and Heitmueller and Inglis (2007)). McGarry (2006) shows little evidence on labor market attachment and caregiving later in life using longitudinal data.

2 Van Houtven, et al. (2013) points out several major concerns regarding the previous literature on the causal relationship between caregiving and work. First, much of the older literature ignored the endogeneity problem between caregiving and work that was addressed by newer literature producing mixed results. Second, much of the recent longitudinal literature focused on Europe and is difficult to generalize. Third, much of the literature examined either the extensive or intensive work margin or impact on wages and a comprehensive effect of caregiving is not difficult to capture on total impact.
} 
evidence to support this. Surprisingly, to the best of our knowledge, there are few studies on the effect of the public LTCI program on labor supply. Shimizutani et al. (2008) used longitudinal data and found that the introduction of the LTCI program had a large and positive effect on the female labor supply; the program enhanced the probability of being employed by $30-60 \%$, working days per week by $40-60 \%$, and working hours per day by $50-70 \%$. In contrast, Tamiya et al. (2011) found that the introduction of the LTCI program increased the probability of being employed mainly for the high-income group and weekly working hours by 4.6 hours for the group, though they did not use longitudinal data covering before and after 2000 . Note that those two studies focused on the effect of the introduction of the LTCI program on female labor supply attachment. Surprisingly, virtually no empirical studies examined the causal relationship between caregiving and work attachment when the public LTCI program matured despite the expanding costs of formal care provision through the program. ${ }^{3}$ During the decade, the use of long-term care services grew considerably and LTCI costs doubled from 4.0 trillion yen in FY2000 to 8.4 trillion yen in FY2011. The National Council on Social Security (2006) estimated that LTCI costs will increase from 19 to 24 trillion yen by FY2025 (from $3.2 \%$ to $4.1 \%$ of GDP).

\footnotetext{
3 An attempt is Sugawara and Nakamura (2013). They focus on co-residing females and do not address endogeneity issues between work decision and care provision. In addition, they did not provide any analysis on male caregivers.
} 
Empowered by micro-level data from a large-scale survey, we examine the impact of care provision for parents at home on labor market outcomes in terms of work and employment status and hours worked. To do so, we focus on how labor market outcomes of a main caregiver at home are affected by providing help for his/her parents (Lilly, et al., 2010). We also relate those examinations with the public LTCI program to explore whether the LTCI program could mitigate a caregiver's disadvantages in the labor market. While our data limits our analysis to co-residential caregiving, there is little consensus on the effect of caregivers' residence on labor market outcomes; Ettner (1996) found only non-coresidential female caregivers experience significant short-term negative work effects in the U.S. while co-residential caregiving has stronger negative effects on work in Europe (Casado-Marin et al., 2011; Heitmueller, 2007; Heitmueller et al., 2010). This paper proceeds as follows. Section 2 provides a concise overview of the relevant aspects of Japan's LTCI program. Section 3 explains the dataset used in this study. Section 4 describes our empirical approach and discusses the estimation results. The final section provides our conclusions.

\section{Japan's public long-term care insurance program}

This section provides a brief overview of the public long-term care insurance (LTCI) program in Japan, focusing on at-home care that is relevant to the current 
paper. ${ }^{4}$ A distinct feature of Japan's LTCI program is its “decentralized yet centralized" approach (Mitchell, Piggott and Shimizutani, 2006, 2008). ${ }^{5}$

The LTCI program insurers are municipalities or their alliances. The participation in the program is mandatory. The insured persons are divided into Category 1 (individuals aged 65 and older) and Category 2 (individuals aged 40-64). In principle, only Category 1 persons are eligible for LTC services once certified. The program is operated as a pay-as-you-go program, financed half by premiums levied on insured persons and half by contributions from the general tax revenue from central and local governments. LTCI premiums differ across insurers and are subject to revision every three years, means tested and categorized into six levels.

When a beneficiary aged 65 and older requires long-term care support, one needs to be certified to receive services by application to the relevant municipality. The eligibility criteria are uniform nationwide and determined by information on physical and mental health. Any certified person is assigned one of the seven care levels linking the necessity of support and the service allowance to be received. Care levels 1-5 are for disabled individuals in need of LTC to help with basic activities of

\footnotetext{
${ }^{4}$ The description of this section is largely based on Shimizutani (2013).

5 The centralized elements are aspects that the eligibility and certification process, type of services to be insured, fee for service and co-payment are determined and uniformly implemented by the central government. In contrast, the decentralized elements are aspects where insurers and insurance premiums vary across regions and are collected by the municipality and types of care to be used are determined by a care manager and supplied by a variety of providers including for-profit organizations.
} 
daily living (ADL) and who are eligible for "LTCI benefits" including institutional care services, at-home care services, and community-based services, whose provision is based on a care plan devised by a certified care manager selected by the beneficiary. In contrast, "Support Required" levels 1-2 are for individuals who can live independently but are in need of care to assist with instrumental activities of daily living (IADL) and who are eligible for "preventive benefits", which are based on a care plan for prevention.

A certified person can use LTC services with a flat $10 \%$ co-payment $(90 \%$ is paid by insurance) for each insured service up to a monthly ceiling amount depending on care levels, regardless of income level. In reality, most clients use $40-60 \%$ of the ceiling amounts (Tamiya et al., 2011). The fee schedule is set by the government and revised every three years, depending on the service (fee for service) irrespective of income level or family type (but no cash allowances), which is categorized into three types: for at-home care services, institutional care services or community-based services. ${ }^{6}$ Care service providers include local governments, semi-public welfare

\footnotetext{
6 A detailed description of institutional care and community-based care is provided by Shimizutani (2013). At home care services include: home-help services (housekeeping and personal care), home-visiting nurse, home-visit bathing, home-visit rehabilitation, elderly care provided in for-profit private homes, welfare device leasing, at-home medical care management counseling, allowances for the purchase of welfare devices and for-home renovations that are received at home, day services (care with rehabilitation), short-stay care (service) received outside the home.
} 
corporations, non-profit organizations, hospitals, and for-profit companies, all of

which are licensed and supervised by the prefectural government.

\section{Data description}

This study uses micro-level data from the Comprehensive Survey of Living

Conditions, (henceforth, CSLC survey) compiled by the Ministry of Health, Labour

and Welfare. A large-scale CSLC survey has been performed every three years since

1986 and we use the data from 2010 , which is the most recent available. ${ }^{7}$ One

advantage of the CSLC survey is the unusually rich number of households and

individuals in the sample that are selected nationwide. The sampling design in the

2010 survey was to choose 5,510 survey locations randomly from the census blocks

(the total number is less than a million) and then to survey all the households $(289,363$

households) and all household members (about 750,000 persons) for the household

survey and the health survey. ${ }^{8}$ The number of households that responded to the

survey effectively was 228,864 . We use the information that is available only in the

household survey related to health and long-term care. While the long-term care

\footnotetext{
7 A smaller scale survey is conducted in the other years.

8 The survey has two additional questionnaires. The income and saving survey was submitted to all the households (35,971 households) and their members (about 100,000 persons) in 2,000 census blocks among 5,510 that were randomly chosen for the household and health surveys. The number of households that responded effectively was 26,115 . In contrast, the long-term care survey asked 7,192 persons who are eligible to use public long-term care insurance services to complete it from 2,500 blocks who were randomly chosen among 5,510 blocks. The final sample was 5,912 persons.
} 
survey contains some useful information on the use of care service, we do not use it since the sample size is too small (5,912 persons) to perform analysis of this study and the distribution of care levels in the survey differs dramatically from the population. ${ }^{9}$

From the household survey sample, we select individuals based on the following sample selection criteria. First, we select both males and females aged between 40 and 60 years old and who do not require any help since they are likely to provide family care. Second, we choose individuals who co-reside with a parent whose age is above 65 years old. To avoid complicated interaction within a household, we limit our analysis to cases where the parent is a widower, widow, or separated and thus there is no spouse who can provide informal care to the parent. Those two criteria are employed to focus on a typical combination of at-home caregivers and at-home care receivers in Japan in terms of age range so as to mitigate unobserved heterogeneity in the individuals in the sample. Then, we omit any individuals from the sample if a family member needs any help that is not related to LTC since we focus on the effect of LTC provision on labor outcome. We also eliminate any individuals who do not live together with their parents since no information of LTC use of the parents including whether they are eligible to use LTCI services is available in the data and we focus on the effect of LTC provision on co-resident caregivers. Finally,

\footnotetext{
9 While it is stated that the objects in the income and saving survey and the long-term care survey are randomly chosen from the same blocks (namely 5,510 blocks), there is no household that responded to both surveys.
} 
information on education attainment is indispensable to the analysis of labor supply

decisions. ${ }^{10}$ We exclude individuals who have no educational attainment (less than

$0.005 \%$ of the observations) while we create a dummy variable for individuals whose

educational attainment is missing (about $5 \%$ of the sample for the analyses below).

Then, our basic sample size is 9,707 for males and 9,216 for females.

Table 1 presents the summary statistics of the variables used in the analysis. In

what follows, we perform our analysis separately for males and females. ${ }^{11}$ First, we

look at labor market outcomes. Whether working or not ("work") to measure

extensive margins differs between males and females; 90.8 percent of males are at

work (only 9.2 percent are not at work) while 76.7 percent of females are at work

(23.3 percent not at work). Moreover, employment status among workers is also

heterogeneous between males and females. The most dominant for males at work is

regular workers (52.7 percent), followed by the self-employed (19.5 percent) and

non-regular workers (18.6 percent). In contrast, the most dominant for females is

non-regular workers (34.9 percent), followed by regular workers (28.1 percent) and

the self-employed (13.7 percent). The average working hours per week ("wh") that

${ }^{10}$ In the CSLC survey, information of educational attainment was available in 2010 for the first time. In other words, any surveys prior to 2010 suffer from a lack of essential information on labor supply.

11 Some studies find stronger work effects for female caregivers compared to males (Carmichael and Charles, 2003) while others do not (Bolin et al., 2008; Johnson and LoSasso, 2006). Dentinger and Clarkberg (2002) examined the effect of informal care provision on the transition to retirement and found that wives caring for husbands have retirement odds five times greater than non-caregiving women. However, they did not find care provision for parents or parents in-law experience hastens the transition to retirement, which is the case for both men and women. 
measure intensive margins is 47.4 hours for males and 37.4 hours for females,

respectively. ${ }^{12}$ The following four variables ("experience", "public", "fsize2" and "fsize3") are available only for current workers and are missing for individuals who are not at work. The average years of experience for the current job ("experience") is 22.5 years and 16.5 years for males and females, respectively, which is likely to affect working hours and thus is used in the intensive margin regressions. In addition, about 8 percent of the individuals are government employees ("public") for both sexes.

While the share of males working for a large firm ("fsize3", a large firm is defined as one with more than 500 employees), 16.7 percent, is larger than that of females (13.0 percent), the share of males working for a medium size firm ("fsize2", a medium size firm is defined as one with more than 100 employees but less than 500 employees) is 14.4 percent, which is similar to that of females (15.2 percent).

Second, the main caregiver consists of 7.7 percent for males and 19.9 percent for females, showing that females are more likely to provide care mainly. The main caregiver is identified from the response to the survey and an indicator variable allocating 1 for a main caregiver and zero otherwise is used as a key variable in the analysis below. Third, focusing on individual characteristics, the average age ("age") is 51.7 and 50.8 for males and females, respectively. The proportion of married

12 We omitted the individuals with the top and bottom 1 percent of "wh" to mitigate the influence of extreme value of wh. 
individuals ("marriage" is an indicator) is 70.2 percent and 79.3 percent for each gender and the proportion of individuals having at least one child less than 18 years old ("kid") is 30.7 percent and 31.6 percent, respectively. Educational attainment also differs by gender. For males, the dominant proportion is found in senior high school graduates ("edu2") consisting of half, followed by university or above graduates ("edu4"). The proportion of junior high school graduates ("edu1") or of junior college/training school graduates is more or less 10 percent. Health status (health) is a binary variable allocating 1 if the self-rated health status is poor or not so good while it allocates zero if the self-rated health status is good, relatively good, or neither good nor bad. 15.1 percent of the male respondents and 17.4 percent of the female respondents answered that their self-rated health status is poor or not so good. About 95 percent of the individuals in the sample have their own house for both sexes. This is probably because our sample is restricted to individuals co-residing with their parents. The average logarithm of monthly household expenditure per capita ("lexpc"), which is a proxy of the living standard, is comparable between males and females. ${ }^{13}$ Finally, focusing on the characteristics of care receivers, the proportion of parents who are approved to use LTC services from the public insurance is 14.8 percent if the respondent is male and 17.3 percent if female. The average of parent

\footnotetext{
${ }^{13}$ While other economic variables (e.g., annual income or financial savings) are available for a part of the sample who responded to the income and saving survey, we did not use them since the sample size is reduced to about one-tenth.
} 
age ("pa") is 78.8 years old for the male sample and 79.9 years old for the female sample. 15-16 percent of the parents answer that their self-rated health is poor or not so good. Females dominate the parent's gender ("pg") and males constitute about 15-16 percent of single parents in the sample. The gender balance among the single parents may be accounted for by explanations such as females live longer than males or males are more likely to remarry. About 41-43 percent of the single parents have at least one child living apart.

\section{Empirical approach and results}

This section empirically examines the effect of being a main caregiver on labor market outcomes in terms of work status (work or not), employment status (regular, non-regular or self-employed) and weekly working hours. The sign and size of the labor supply effect of care provision is not ex ante determined; a caregiver may reduce working hours or quit a job to provide care at home or may retain working hours for salary purposes and instead decrease leisure time or may increase working hours to compensate for the out-of-pocket burden incurred to use the service through the public LTCI program. Thus, the effect of care provision on labor market attachment requires empirical investigation.

The basic specification we used is described as follows. 
$Y_{i}=\alpha+\beta *$ Maincaregiver $_{i}+\gamma *$ Eligibility $_{i}+\delta_{1} * X_{i}+\varepsilon_{i}$

where $i$ refers to an individual in the sample. The dependent variable $\left(Y_{i}\right)$ takes three forms: work status, employment status and working hours, which are explained below in detail. The explanatory variables include a constant term $(\alpha)$, an indicator that allocates 1 for being a main caregiver (Maincaregiver ${ }_{\text {, }}$, henceforth "caregiver dummy"), the main interest of this paper and a vector of a variety of basic attributes of the respondents that are included in Table $1\left(X_{i}\right)$; age, squared age of the respondent, marital status (indicator that allocates 1 if married and zero otherwise), child status (indicator that allocates 1 if having at least one child aged 18 or below and zero otherwise), educational attainment (dummy variables), indicator for subjective health status (indicator that allocates 1 if subjective health status is poor and zero if subjective health status is good or neither good nor bad), house tenancy status (indicator that allocates 1 if having own house and zero otherwise), logarithm of monthly household expenditure per capita, and prefecture dummies (47 prefectures in Japan).

Moreover, we added a variable (Eligibility), which is an indicator that allocates 1 if a parent is certified to use public LTCI services and 0 otherwise (henceforth "eligibility dummy"). We include this variable on the right hand side to capture the effect of the public LTCI program on the work decision. Ideally, we should be able to 
include the interaction term between caregiver dummy and eligibility dummy in empirical specifications. However, the correlation between this interaction term and eligibility dummy ( 0.53 for the male sample and 0.87 for the female sample) or caregiver dummy ( 0.76 for the male sample and 0.79 for the female sample) is high, distorting the estimation results. Thus, we just include the eligibility dummy as it is to grasp the "average" effect of the LTCI program on the work decision.

\subsection{Effect of being a main caregiver on work status}

First, we explore whether a main caregiver is less likely to be at work or not, so as to measure extensive margin. The dependent variable is a binomial choice indicator and one that allocates 1 if a respondent is at work and zero otherwise. Table 2 presents the coefficients on the main variables for males using the linear probability model. The first two columns (Columns (1) and (2)) show the coefficients obtained by OLS estimation. In Column (1), the coefficient on the caregiver dummy is negative and significant, showing that being a main caregiver reduces the probability of working by 7.6 percent. The coefficient on age is positive and on age squared is negative, both of which are significant. Males who are married or have kids under 18 are more likely to work. The junior high school graduates (the base case) are significantly less likely to work than senior high school graduates, two-year college 
graduates, and university and above graduates. Males who are healthier or have their own house or larger household expenditure per capita are more likely to work.

Column (2) shows the results by adding the eligibility dummy. The coefficient on the caregiver dummy is negative and significant, showing the probability of working for the main caregiver is reduced by 8.0 percent. Moreover, the coefficient on the eligibility dummy is positive but insignificant, suggesting that even if his parent is certified to use LTC services, this does not help him work.

So far, we have not controlled for the endogeneity between being a main caregiver and probability of working. However, it is possible that work status affects whether a person is a caregiver and the caregiver dummy is endogenous. As such, we need to address the endogenous relationship between the dependent variable and the main variable of interest. One way to address the issue is to employ instrumental variable estimation. Our instrument variables are the age, health status, and gender of a parent. In addition, we include the information on whether a parent has children living apart or not in the set of the instrumental variables. This last instrument is further categorized depending on where the child closest in physical distance to the parent lives as follows: 0 if no children living apart (the base category), 1 if the child lives within the same building, 2 if living in the same site, 3 if living in the neighborhood, 4 if living in the same municipality, and 5 otherwise. The set of 
instrumental variables is strong which is evident by the fact that the F value of the first stage significantly exceeds 20 .

Columns (3) and (4) of Table 2 present the coefficients using IV estimation (linear probability model with IV); Column (3) without the eligibility dummy and Column (4) with the eligibility dummy. The coefficient on the caregiver dummy is negative and significant in Columns (3) and (4), showing the probability of working is reduced by 13.8 percent or 20.2 percent, respectively. Notably, the sizes of the coefficients in absolute value in IV estimations are much larger than those in the corresponding OLS estimations. The coefficient on the eligibility dummy (in Column (4)) is positive but only marginally significant at the 15 percent level. That is, if the parent is certified to use public LTCI services, LTCI may mitigate the negative impact of being a main caregiver (or improve the probability of working) by 4.1 percent, but this effect is only marginally significant. Furthermore, the magnitude of the mitigating effect of LTCI eligibility is significantly smaller than the negative effect of being a caregiver, implying the negative effect largely remains.

In sum, male main caregivers are less likely to work than male non-caregivers by about 7.6-20.2 percent depending on the model we use. To examine the effect of the public LTCI program on work probability, we include the eligibility dummy since once those needy parents are approved, they are entitled to use LTC services at $10 \%$ 
coinsurance. However, the effect of mitigating the disadvantage of main caregivers is marginal from two aspects. First, the coefficient of the eligibility dummy is positive but is only marginally significant. Second, the magnitude of the coefficient of the eligibility dummy is positive but much smaller in absolute value than the negative effect of being a main caregiver on work.

Next, we perform the same analysis for females. Table 3 presents the coefficients obtained by the linear probability model using OLS (Columns (1) and (2)) and the linear probability model using the IV to address the endogeneity (Columns (3) and (4)). First, we observe negative and significant coefficients on the caregiver dummy, showing that female main caregivers are significantly less likely to work. Although those patterns are qualitatively the same as those for males, the size of the negative effect is significantly larger for females than for males; the probability of working is reduced by 9.3-58.3 percent for female caregivers (7.6-20.2 percent for male). The pattern in the remaining coefficients is also similar to those in males in Table 2 except the coefficient of LTCI eligibility. For females, the coefficient on the eligibility dummy is positive and statistically significant (Column (4)) once the indicator of being the main caregiver is instrumented. Note that the magnitude of the coefficient of the eligibility dummy is much larger for females (33.5 percent) than for males (4.1 percent), implying that LTCI's role of mitigating the negative effect of 
being a main caregiver is larger for females than for males. However, the effect of LTCI eligibility is not sufficient to cancel out the very large negative effect of being a main caregiver.

In sum, the qualitative results for females are similar to those for males, but the magnitude is larger for females than for males. Female main caregivers are less likely to work than female non-caregivers by about 9.3-58.3 percent depending on which model we use. This magnitude of the effect for females is larger than that for males. Contrary to males, the public LTCI program seems to mitigate the disadvantage of main caregivers, which is evident in the positive and significant coefficient in Column (4) of Table 3. However, the positive effect is very limited so that it cannot eliminate the large negative effect of being a main caregiver on work.

\subsection{Effect of being a main caregiver on employment status}

We now focus on the effect of being a main caregiver on employment status: regular worker, non-regular worker or self-employed. The basic specification is the same as the work status analysis but there are some differences. The dependent variable is now a multiple choice and thus a multinomial choice indicator: 1: not work (base category), 2: non-regular worker, 3: regular worker, 4: self-employed. The explanatory variables are exactly the same as the previous analysis; indicator for 
being a main caregiver, a variety of basic attributes of the respondents, and indicator

for LTCI eligibility. The coefficients are obtained by multinomial logit estimation and multinomial logit estimation with a control function method as per Kuksov and Villas-Boas (2008) and Petrin and Train (2010). The latter approach deals with endogeneity between the dependent variable and the caregiver dummy through a control function method with a set of exclusion restrictions. For the variables of exclusion restrictions, we use the set of instrumental variables used in sub-section 4.1. Concretely, first, we estimate the reduced form for an indicator of being a main caregiver, where a variety of basic attributes of the respondents, indicator for LTCI eligibility, and the set of exclusion restrictions are used as explanatory variables. Then, we obtain the residual of the regression ("resid"). After that, we estimate the multinomial logit models on employment status with the explanatory variables and the residual from the first-stage regressions. The bootstrapped standard errors are estimated.

Table 4 presents the coefficients for males. Since none of the coefficients of "resid" are statistically significant in the multinomial logit regression and we cannot reject the hypothesis that all the coefficients of "resid" are jointly zero, a simple multinomial logit analysis may be sufficient in the case of males. Thus, we show only the estimation results of simple multinomial logit in Table 4. The marginal effects of 
being a main caregiver and LTCI eligibility dummy, together with raw estimation results are shown.

We observe that a male main caregiver is significantly more likely to be self employed by 4.1 percent or not at work by 4.6 percent than male non-caregivers. In contrast, a male main caregiver is significantly less likely to be a regular worker by 8.4 percent. Put differently, a male caregiver has a significantly lower chance of working on a regular basis and a significantly higher chance of being self-employed or not at work and the size of the effect is larger in the former, suggesting it is difficult for males to be a regular worker once they are providing informal care at home mainly. The marginal effect of LTCI eligibility status is positive and statistically significant for regular work and negative and statistically significant for self-employed, suggesting LTCI eligibility of the parent encourages a main caregiver to be a regular worker while discouraging a main caregiver to fall into the category of self-employed. However, the marginal effect of being a main caregiver is larger than that of LTCI eligibility in absolute value, implying LTCI eligibility of the parent only partially helps the main caregiver especially in the case of a regular worker. The pattern in the remaining coefficients is similar to those in the results for work probability that are examined above. 
Table 5 shows the marginal effects and the coefficients for females. The results of the simple multinomial logit (Columns (1)-(4)) show that a female main caregiver is significantly more likely to be self-employed by 2.3 percent and not be at work by 8.8 percent. The probability of not being at work is much larger (by more than for 4 percent) for females than for males (4.6 percent). In contrast, a female main caregiver is significantly less likely to work on a regular basis by 8.8 percent. A major difference between the case of males and females is the marginal effects of the LTCI eligibility dummy. For females, none of the marginal effects of the LTCI eligibility dummy is significant, implying LTCI has no influence on the employment status of females. Next, we consider the endogeneity between the dependent variable and the caregiver dummy using the control function method explained above (Columns (5)-(8)). All the residual terms "resid" in the estimation results are positive and statistically different from that for the base category. Furthermore, we reject the hypothesis that all the coefficients of "resid" terms are jointly zero at the 1 percent level (chi-squared value is 17.41). Therefore, for females, it is more appropriate to view the results of the multinomial logit with the control function method. Compared to the marginal effects obtained from the simple multinomial logit, there are no changes in the qualitative results of those with the control function method, except that of being a main caregiver for the self-employed. In Column (8), the marginal 
effect of being a main caregiver is now negative but statistically insignificant. More importantly from a quantitative aspect, the marginal effects of being a main caregiver on not being at work and on regular work are much larger in absolute value than those obtained from the simple multinomial logit model. A female main caregiver is significantly more likely to not be at work by 27.6 percent and less likely to be a regular worker by 19.1 percent. Thus, the negative impact of being a main caregiver on being a regular worker and positive impact on not being at work are very large. None of the marginal effects of the LTCI eligibility dummy is significant, implying LTCI has no influence on the employment status of females, even after controlling for endogeneity.

In sum, the negative effect of family care on main caregivers is more serious for females than for males; females are more likely to quit working than males once they become a main caregiver and are less likely to be at work on a regular basis.

\subsection{Effect of being main caregiver on working hours}

Lastly, we explore the effect of being a main caregiver on working hours to capture the impact on the internal margin. The dependent variable is working hours per week. The independent variables are the same as those in the previous regressions (indicator for being a main caregiver, a variety of basic attributes of the respondents, 
and indicator for LTCI eligibility). In addition, the length of time at the current work (experience), dummy for public worker (public) and medium size firm dummy (fsize2) and large firm dummy (fsize3) are included as independent variables. We use simple OLS and IV estimation, latter of which addresses the endogeneity between working hours and the caregiver dummy. The set of instrumental variables is the same as that in the previous analysis.

Table 6 presents the results for males. In the results of OLS estimations (Columns (1) and (2)), weekly working hours of a male main caregiver are shorter by 1.36-1.78 hours than that of male non-caregivers. In the latter specification (Column (2)), we include the LTCI eligibility dummy, whose coefficient is positive and statistically significant. This implies LTCI eligibility mitigates the negative effect of being a main caregiver by 0.87 hours. However, this effect is smaller than the negative effect of being a main caregiver. Columns (3) and (4) show the results of IV estimations. The F-value of the first stage significantly exceeds 20 . Once the indicator of being a main caregiver is instrumented, the coefficient of the indicator still becomes negative but statistically insignificant in Column (3). This holds even after including the LTCI eligibility dummy in Column (4). The coefficient of the indicator of being a main caregiver is negative but statistically insignificant. At the same time, 
in IV estimation of Column (4), the coefficient of the LTCI eligibility dummy is still positive but now statistically insignificant.

Table 7 presents the results for females. In the results of OLS estimations (Columns (1) and (2)), weekly working hours of a female main caregiver are shorter by $2.14-2.38$ hours than that of female non-caregivers. Note this magnitude for females in absolute value is larger than that for males. Contrary to the OLS result for males, the coefficient of the LTCI eligibility dummy is negative although statistically insignificant, implying the LTCI program does not mitigate the negative impact on working hours of being a main caregiver. Columns (3) and (4) show the results of IV estimations. The F-value of the first stage significantly exceeds 20 . The estimated negative effects of being a main caregiver on working hours are much larger than those in OLS: 7.62-13.03 hours. Similar to the case of the IV estimation for the extensive margin, the size of the coefficients in absolute value in IV estimations are much larger than those in the corresponding OLS estimations. In Column (4), the coefficient of the LTCI eligibility dummy is positive and statistically significant. Thus, if the parent has LTCI eligibility (hence, receiving some LTC services), that helps increase the working hours of the caregiving household's women by 6.87 hours on average. However, this mitigation effect of LTCI is significantly smaller than the 
negative effect of being a main caregiver on working hours, leaving a female caregiver with about 6 hours less working hours than a female non-caregiver.

In sum, if we consider the IV estimation results, the situation differs significantly between males and females. For males, neither being a main caregiver nor the LTCI eligibility affect working hours. In contrast, being a main caregiver has a large negative effect on working hours in the case of females. LTCI eligibility only partially mitigates the large negative effect. These differences between males and females might stem from the difference in employment status between males and females. Although not shown, about half of the working male main caregivers (51.3 percent) work as a regular worker, implying adjustment of working hours is more difficult for them than for those in non-regular work or self-employed. In such a case, a parent's LTCI eligibility would have little effect on working hours. In contrast, only 30.9 percent of the working female main caregivers work as a regular worker. The remaining 70 percent of the female main caregivers are either non-regular workers or self-employed, who can work more flexibly than regular workers. Then, the LTCI eligibility of a parent becomes important as it could mitigate the negative effect of being a main caregiver. Thus, these differences between males and females might result in very different outcomes. 


\section{Conclusion}

This paper examines the labor supply effect of family care provision for Japanese households in 2010, ten years after the introduction of the public long-term care insurance program. We found that family care provision adversely affects labor market outcomes of main caregivers such as probability of working, employment status and hours worked.

Our empirical results show that females are more vulnerable than males once they become main caregivers: females are less likely to work and have less working hours even if they can work. Moreover, our results suggest that the public LTC program seems to only partially mitigate the disadvantages of main caregivers both for males and females. There is no clear evidence that receiving services offered by the public LTCI program provides main caregivers with sufficient help so that the disadvantage of main caregivers is largely mitigated. Further research should address why any positive effect of the LTCI program on labor market outcomes is modest compared with the negative effect of being a main caregiver empowered by a longitudinal dataset such as Japanese Study on Aging Retirement (JSTAR). 


\section{Reference}

Bolin, Kristian, Björn Lindgren and Petter Lundbor (2008). "Your Next of Kin or Your Own Career? Caring and Working among the 50+ of Europe," Journal of Health Economics 27(3), 718-738.

Carmichael, Fiona and Susan Charles (1998). "The Labour Market Costs of Community Care," Journal of Health Economics 17(6), 747-765.

Carmichael, Fiona and Susan Charles (2003). "The Opportunity Costs of Informal Care: Does Gender Matter?" Journal of Health Economics 22(5), 781-803.

Casado-Marín, David, Pilar Garcia-Gomez and Ángel López-Nicolás (2011). "Informal Care and Labour Force Participation among Middle-aged Women in Spain," SERIEs: Journal of the Spanish Economic Association 2(1), 1-29.

Dentinger, Emma and Martin Clarkberg (2002). "Caregiving and Retirement Timing among Men and Women: Gender and Caregiving Relationships in Late Midlife. Journal of Family Issues, 23(7), 857-879.

Ettner, Susan (1996). "The Opportunity Costs of Elder Care," Journal of Human Resources 31(1), 189-205.

Heitmueller, Axel (2007). "The Chicken or the Egg? Endogeneity in Labour Market Participation of Informal Carers in England," Journal of Health Economics 26(3), 536-559.

Heitmueller, Axel and Kirsty Inglis (2007). "The Earnings of Informal Carers: Wage Differentials and Opportunity Costs," Journal of Health Economics 26(4), 821-841.

Heitmueller, Axel, Michaud, Pierre-Carl and Zafar Nazarov (2010). "A Dynamic Analysis of Informal Care and Employment in England," Labour Economics 17(3), 455-465.

Johnson, Richard, Anthony LoSasso (2006). "The Impact of Elder Care on Women's Labor Supply at Midlife," Inquiry 43(3), 195-210.

Kuksov, Dmitri and Miguel Villas-Boas (2008). "Endogeneity and Individual Consumer Choice," Journal of Marketing Research 45(6), 702-714.

Lilly, Meredith, Audrey Laporte and Peter Coyte (2010). "Do they Care Too Much to Work? The Influence of Caregiving Intensity on the Labour Force Participation of Unpaid Caregivers in Canada," Journal of Health Economics 29(6), 895-903.

McGarry, Kathleen (2006). "Does Caregiving Affect Work? Evidence Based on Prior Labor Force Experience," In Health Care Issues in the United States and Japan, David A. Wise, eds. University of Chicago Press. 
Ministry of Health, Labor and Welfare (MHLW). 2002. "Long-term Care Insurance in Japan.” Online: http://www.mhlw.go.jp/english/topics/elderly/care/index.html.

Mitchell, Olivia, John Piggott and Satoshi Shimizutani. 2006. "Aged-care Support in Japan: Perspectives and Challenges," Benefits Quarterly, 7-18, $1^{\text {st }}$ Quarter.

Mitchell, Olivia, John Piggott and Satoshi Shimizutani. 2008. "An Empirical Analysis of Patterns in the Japanese Long-term Care Insurance System," Geneva Papers on Risk and Insurance - Issues and Practice, 33(4), 694-709.

National Council on Social Security. 2006. "Iryo, Kaigo Hiyou no Simyuresyon Kekka ni tsuite," [On the Simulation Result on Medical and Long-term Care Costs].

Petrin, Amil and Kenneth Train (2010). "A Control Function Approach to Endogeneity in Consumer Choice Models," Journal of Marketing Research 47(1), 3-13.

Shimizutani, Satoshi. 2013. "The Future of Long-term Care in Japan," RIETI Discussion Paper Series 13-E-064.

Shimizutani, Satoshi, Wataru Suzuki and Haruko Noguchi. 2008. "The Socialization of At-home Elderly Care and Female Labor Market Participation: Micro-level Evidence from Japan," Japan and the World Economy, 20(1), 82-96.

Sugawara, Shinya and Jiro Nakamura (2013). "Is Elderly Care Socialized in Japan? Analyzing the Effects of the 2006 Amendment to the LTCI on the Female Labor Supply," CIRJE Discussion Papers CIRJE-F-888.

Tamiya, Nanako, Haruko Noguchi, Akihiro Nishi, Michael R Reich, Naoki Ikegami, Hideki Hashimoto, Kenji Shibuya, Ichiro Kawachi and John Creighton Campbell. 2011. "Population aging and wellbeing: lessons from Japan's long-term care insurance policy." Lancet in a Series of six papers about Japan's universal health care at 50 years, $48-57$.

Van Houtven, Courtney Harold, Norma Coe and Meghan Skirad (2013). "The Effect of Informal Care on Work and Wages," Journal of Health Economics, 32(1), 240-252.

Wolf, Douglas and Beth Soldo (1994). "Married Women's Allocation of Time to Employment and Care of Elderly Parents," Journal of Human Resources 29(4), $1259-1276$. 
Table 1: Descriptive statistics

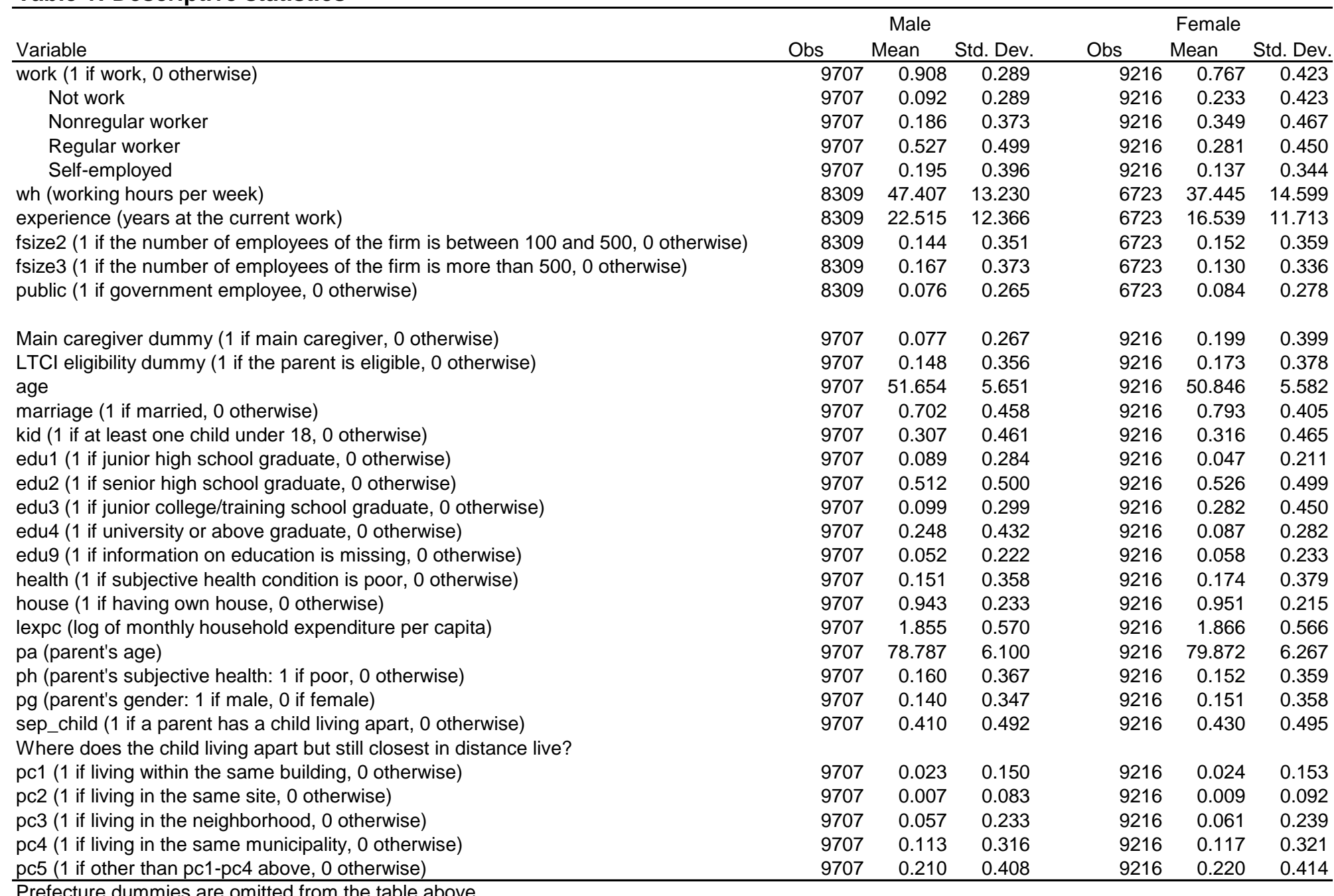


Table 2: Work or not (Male, OLS and IV)

\begin{tabular}{|c|c|c|c|c|}
\hline VARIABLES & $\begin{array}{l}\text { (1) } \\
\text { OLS }\end{array}$ & $\begin{array}{c}(2) \\
\text { OLS }\end{array}$ & $\begin{array}{l}\text { (3) } \\
\text { IV }\end{array}$ & $\begin{array}{l}\text { (4) } \\
\text { IV }\end{array}$ \\
\hline Main caregiver dummy & $\begin{array}{c}-0.076^{\star * *} \\
{[0.014]}\end{array}$ & $\begin{array}{c}-0.080^{\star * *} \\
{[0.014]}\end{array}$ & $\begin{array}{c}-0.138^{\star *} \\
{[0.057]}\end{array}$ & $\begin{array}{c}-0.202^{* *} \\
{[0.091]}\end{array}$ \\
\hline LTCI eligibility dummy & & $\begin{array}{c}0.007 \\
{[0.011]}\end{array}$ & & $\begin{array}{c}0.041 \\
{[0.027]}\end{array}$ \\
\hline age & $\begin{array}{c}0.064^{* * *} \\
{[0.010]}\end{array}$ & $\begin{array}{l}0.064^{* * *} \\
{[0.010]}\end{array}$ & $\begin{array}{c}0.065^{\star * *} \\
{[0.010]}\end{array}$ & $\begin{array}{c}0.066^{* * *} \\
{[0.010]}\end{array}$ \\
\hline age squared & $\begin{array}{c}-0.001^{* * *} \\
{[0.000]}\end{array}$ & $\begin{array}{c}-0.001^{* * *} \\
{[0.000]}\end{array}$ & $\begin{array}{c}-0.001^{* * *} \\
{[0.000]}\end{array}$ & $\begin{array}{c}-0.001^{* * *} \\
{[0.000]}\end{array}$ \\
\hline marriage & $\begin{array}{c}0.156^{\star * *} \\
{[0.012]}\end{array}$ & $\begin{array}{c}0.155^{\star \star *} \\
{[0.012]}\end{array}$ & $\begin{array}{c}0.149^{* * *} \\
{[0.013]}\end{array}$ & $\begin{array}{c}0.139^{\star * *} \\
{[0.015]}\end{array}$ \\
\hline kid & $\begin{array}{c}0.017^{* * *} \\
{[0.006]}\end{array}$ & $\begin{array}{c}0.017^{* * *} \\
{[0.006]}\end{array}$ & $\begin{array}{c}0.018^{* * *} \\
{[0.006]}\end{array}$ & $\begin{array}{c}0.020^{* * *} \\
{[0.006]}\end{array}$ \\
\hline edu2 & $\begin{array}{l}0.028^{* *} \\
{[0.012]}\end{array}$ & $\begin{array}{l}0.028^{* *} \\
{[0.012]}\end{array}$ & $\begin{array}{l}0.028^{* *} \\
{[0.012]}\end{array}$ & $\begin{array}{l}0.028^{* *} \\
{[0.012]}\end{array}$ \\
\hline edu3 & $\begin{array}{c}0.044^{* * *} \\
{[0.016]}\end{array}$ & $\begin{array}{c}0.044^{* * *} \\
{[0.016]}\end{array}$ & $\begin{array}{c}0.045^{\star * *} \\
{[0.016]}\end{array}$ & $\begin{array}{c}0.046^{* * *} \\
{[0.016]}\end{array}$ \\
\hline edu4 & $\begin{array}{l}0.028^{*} \\
{[0.014]}\end{array}$ & $\begin{array}{l}0.028^{*} \\
{[0.014]}\end{array}$ & $\begin{array}{l}0.028^{* *} \\
{[0.014]}\end{array}$ & $\begin{array}{l}0.028^{\star *} \\
{[0.014]}\end{array}$ \\
\hline edu9 & $\begin{array}{l}0.029^{* *} \\
{[0.013]}\end{array}$ & $\begin{array}{l}0.029^{* *} \\
{[0.013]}\end{array}$ & $\begin{array}{l}0.028^{* *} \\
{[0.013]}\end{array}$ & $\begin{array}{l}0.028^{* *} \\
{[0.013]}\end{array}$ \\
\hline health & $\begin{array}{c}-0.059^{\star \star \star} \\
{[0.012]}\end{array}$ & $\begin{array}{c}-0.059^{\star \star \star} \\
{[0.012]}\end{array}$ & $\begin{array}{c}-0.055^{\star \star \star} \\
{[0.012]}\end{array}$ & $\begin{array}{c}-0.054^{\star \star \star} \\
{[0.012]}\end{array}$ \\
\hline house & $\begin{array}{l}0.034^{\star *} \\
{[0.016]}\end{array}$ & $\begin{array}{l}0.034^{\star *} \\
{[0.016]}\end{array}$ & $\begin{array}{l}0.033^{* *} \\
{[0.016]}\end{array}$ & $\begin{array}{l}0.034^{\star *} \\
{[0.016]}\end{array}$ \\
\hline lexpc & $\begin{array}{c}0.033^{* * *} \\
{[0.006]}\end{array}$ & $\begin{array}{c}0.033^{* * *} \\
{[0.006]}\end{array}$ & $\begin{array}{c}0.034^{* * *} \\
{[0.006]}\end{array}$ & $\begin{array}{c}0.034^{* * *} \\
{[0.006]}\end{array}$ \\
\hline Constant & $\begin{array}{c}-0.858^{\star \star *} \\
{[0.252]}\end{array}$ & $\begin{array}{c}-0.862^{\star \star *} \\
{[0.254]}\end{array}$ & & \\
\hline $\begin{array}{l}\text { Observations } \\
\text { R-squared }\end{array}$ & $\begin{array}{l}9,707 \\
0.111\end{array}$ & $\begin{array}{l}9,707 \\
0.111\end{array}$ & 9,707 & 9,707 \\
\hline F-value of 1 st stage & & & 49.63 & 72.1 \\
\hline Prefecture dummies & Yes & Yes & Yes & Yes \\
\hline
\end{tabular}

Clustered standard errors at prefecture level in brackets

${ }^{* * *} P<0.01,{ }^{* *} P<0.05,{ }^{*} P<0.1$ 
Table 3: Work or not (Female, OLS and IV)

\begin{tabular}{|c|c|c|c|c|}
\hline VARIABLES & $\begin{array}{l}\text { (1) } \\
\text { OLS }\end{array}$ & $\begin{array}{l}(2) \\
\text { OLS }\end{array}$ & $\begin{array}{l}\text { (3) } \\
\text { IV }\end{array}$ & $\begin{array}{l}\text { (4) } \\
\text { IV }\end{array}$ \\
\hline Main caregiver dummy & $\begin{array}{c}-0.094^{* * *} \\
{[0.011]}\end{array}$ & $\begin{array}{c}-0.093^{* * *} \\
{[0.016]}\end{array}$ & $\begin{array}{c}-0.282^{* * *} \\
{[0.047]}\end{array}$ & $\begin{array}{c}-0.583^{* * *} \\
{[0.133]}\end{array}$ \\
\hline LTCI eligibility dummy & & $\begin{array}{l}-0.002 \\
{[0.019]}\end{array}$ & & $\begin{array}{c}0.335^{\star * *} \\
{[0.095]}\end{array}$ \\
\hline age & $\begin{array}{c}0.113^{* * *} \\
{[0.014]}\end{array}$ & $\begin{array}{l}0.113^{* * *} \\
{[0.014]}\end{array}$ & $\begin{array}{c}0.107^{\star * *} \\
{[0.013]}\end{array}$ & $\begin{array}{c}0.109^{* * *} \\
{[0.014]}\end{array}$ \\
\hline age squared & $\begin{array}{c}-0.001^{* * *} \\
{[0.000]}\end{array}$ & $\begin{array}{c}-0.001^{* * *} \\
{[0.000]}\end{array}$ & $\begin{array}{c}-0.001^{* * *} \\
{[0.000]}\end{array}$ & $\begin{array}{c}-0.001^{* * *} \\
{[0.000]}\end{array}$ \\
\hline marriage & $\begin{array}{c}-0.021 \\
{[0.013]}\end{array}$ & $\begin{array}{l}-0.021 \\
{[0.013]}\end{array}$ & $\begin{array}{l}-0.021^{*} \\
{[0.013]}\end{array}$ & $\begin{array}{c}-0.041^{* * *} \\
{[0.015]}\end{array}$ \\
\hline kid & $\begin{array}{c}0.018 \\
{[0.012]}\end{array}$ & $\begin{array}{c}0.018 \\
{[0.012]}\end{array}$ & $\begin{array}{l}0.020^{*} \\
{[0.012]}\end{array}$ & $\begin{array}{c}0.019 \\
{[0.012]}\end{array}$ \\
\hline edu2 & $\begin{array}{c}0.028 \\
{[0.025]}\end{array}$ & $\begin{array}{c}0.028 \\
{[0.025]}\end{array}$ & $\begin{array}{c}0.027 \\
{[0.026]}\end{array}$ & $\begin{array}{c}0.029 \\
{[0.026]}\end{array}$ \\
\hline edu3 & $\begin{array}{l}0.044^{*} \\
{[0.026]}\end{array}$ & $\begin{array}{l}0.044^{*} \\
{[0.026]}\end{array}$ & $\begin{array}{c}0.043 \\
{[0.026]}\end{array}$ & $\begin{array}{l}0.045^{\star} \\
{[0.027]}\end{array}$ \\
\hline edu4 & $\begin{array}{l}0.069^{* *} \\
{[0.032]}\end{array}$ & $\begin{array}{l}0.069^{* *} \\
{[0.032]}\end{array}$ & $\begin{array}{l}0.073^{\star \star} \\
{[0.033]}\end{array}$ & $\begin{array}{l}0.076^{\star *} \\
{[0.034]}\end{array}$ \\
\hline edu9 & $\begin{array}{c}-0.017 \\
{[0.028]}\end{array}$ & $\begin{array}{l}-0.017 \\
{[0.028]}\end{array}$ & $\begin{array}{l}-0.015 \\
{[0.029]}\end{array}$ & $\begin{array}{l}-0.011 \\
{[0.029]}\end{array}$ \\
\hline health & $\begin{array}{l}-0.014 \\
{[0.012]}\end{array}$ & $\begin{array}{l}-0.014 \\
{[0.012]}\end{array}$ & $\begin{array}{c}0.011 \\
{[0.014]}\end{array}$ & $\begin{array}{c}0.014 \\
{[0.016]}\end{array}$ \\
\hline house & $\begin{array}{c}0.014 \\
{[0.021]}\end{array}$ & $\begin{array}{c}0.014 \\
{[0.021]}\end{array}$ & $\begin{array}{c}0.009 \\
{[0.021]}\end{array}$ & $\begin{array}{c}0.007 \\
{[0.022]}\end{array}$ \\
\hline lexpc & $\begin{array}{c}0.001 \\
{[0.008]}\end{array}$ & $\begin{array}{c}0.001 \\
{[0.008]}\end{array}$ & $\begin{array}{c}0.004 \\
{[0.008]}\end{array}$ & $\begin{array}{c}0.005 \\
{[0.008]}\end{array}$ \\
\hline Constant & $\begin{array}{c}-1.901^{* * *} \\
{[0.340]}\end{array}$ & $\begin{array}{c}-1.901^{* * *} \\
{[0.342]}\end{array}$ & & \\
\hline $\begin{array}{l}\text { Observations } \\
\text { R-squared }\end{array}$ & $\begin{array}{l}9,216 \\
0.048\end{array}$ & $\begin{array}{l}9,216 \\
0.048\end{array}$ & 9,216 & 9,216 \\
\hline F-value of 1 st stage & & & 104.35 & 599.63 \\
\hline Prefecture dummies & Yes & Yes & Yes & Yes \\
\hline
\end{tabular}

Clustered standard errors at prefecture level in brackets

${ }^{* * *} P<0.01,{ }^{* *} P<0.05,{ }^{*} P<0.1$ 
Table 4: Not work, nonregular work, regular work, or self-employed? (Male, multinomial logit)

\begin{tabular}{|c|c|c|c|c|}
\hline \multirow[b]{2}{*}{ VARIABLES } & \multicolumn{4}{|c|}{ Multinomial logit with IV } \\
\hline & $\begin{array}{c}\text { Not work } \\
\text { (default } \\
\text { category) }\end{array}$ & $\begin{array}{c}\text { Non-regular } \\
\text { worker }\end{array}$ & $\begin{array}{l}\text { Regular } \\
\text { worker }\end{array}$ & $\begin{array}{c}\text { Self- } \\
\text { employed }\end{array}$ \\
\hline \multicolumn{5}{|l|}{ Marginal effect } \\
\hline Main caregiver dummy & $\begin{array}{c}0.046^{\star * *} \\
{[0.009]}\end{array}$ & $\begin{array}{c}-0.002 \\
{[0.018]}\end{array}$ & $\begin{array}{c}-0.084^{\star * *} \\
{[0.022]}\end{array}$ & $\begin{array}{l}0.041^{* *} \\
{[0.016]}\end{array}$ \\
\hline LTCI eligibility dummy & $\begin{array}{l}-0.006 \\
{[0.011]}\end{array}$ & $\begin{array}{l}-0.003 \\
{[0.012]}\end{array}$ & $\begin{array}{l}0.034^{* *} \\
{[0.015]}\end{array}$ & $\begin{array}{l}-0.024^{*} \\
{[0.014]}\end{array}$ \\
\hline \multicolumn{5}{|l|}{ Estimation results } \\
\hline Main caregiver dummy & & $\begin{array}{c}-0.591^{* * *} \\
{[0.159]}\end{array}$ & $\begin{array}{c}-0.765^{\star * *} \\
{[0.147]}\end{array}$ & $\begin{array}{c}-0.365^{\star *} \\
{[0.155]}\end{array}$ \\
\hline LTCI eligibility dummy & & $\begin{array}{c}0.065 \\
{[0.179]}\end{array}$ & $\begin{array}{c}0.159 \\
{[0.165]}\end{array}$ & $\begin{array}{c}-0.039 \\
{[0.166]}\end{array}$ \\
\hline age & & $\begin{array}{c}0.605^{\star * *} \\
{[0.158]}\end{array}$ & $\begin{array}{l}1.074^{* * *} \\
{[0.108]}\end{array}$ & $\begin{array}{l}0.831^{* * *} \\
{[0.140]}\end{array}$ \\
\hline age squared & & $\begin{array}{c}-0.006^{\star \star *} \\
{[0.002]}\end{array}$ & $\begin{array}{c}-0.011^{\star \star *} \\
{[0.001]}\end{array}$ & $\begin{array}{c}-0.008^{* \star *} \\
{[0.001]}\end{array}$ \\
\hline marriage & & $\begin{array}{l}1.458^{\star * *} \\
{[0.133]}\end{array}$ & $\begin{array}{l}1.768^{\star * *} \\
{[0.128]}\end{array}$ & $\begin{array}{l}1.713^{* * *} \\
{[0.124]}\end{array}$ \\
\hline kid & & $\begin{array}{c}0.607^{\star * *} \\
{[0.122]}\end{array}$ & $\begin{array}{c}0.810^{\star * *} \\
{[0.133]}\end{array}$ & $\begin{array}{c}0.585^{\star * \star} \\
{[0.134]}\end{array}$ \\
\hline edu2 & & $\begin{array}{c}0.117 \\
{[0.145]}\end{array}$ & $\begin{array}{c}0.465^{\star * *} \\
{[0.104]}\end{array}$ & $\begin{array}{c}-0.036 \\
{[0.124]}\end{array}$ \\
\hline edu3 & & $\begin{array}{c}0.340 \\
{[0.229]}\end{array}$ & $\begin{array}{c}0.537^{\star * *} \\
{[0.169]}\end{array}$ & $\begin{array}{c}0.624^{\star \star \star} \\
{[0.202]}\end{array}$ \\
\hline edu4 & & $\begin{array}{c}0.152 \\
{[0.177]}\end{array}$ & $\begin{array}{c}0.450^{* * *} \\
{[0.155]}\end{array}$ & $\begin{array}{c}-0.093 \\
{[0.162]}\end{array}$ \\
\hline edu9 & & $\begin{array}{c}0.047 \\
{[0.217]}\end{array}$ & $\begin{array}{l}0.389^{\star *} \\
{[0.173]}\end{array}$ & $\begin{array}{c}0.124 \\
{[0.186]}\end{array}$ \\
\hline health & & $\begin{array}{c}-0.584^{\star * \star} \\
{[0.116]}\end{array}$ & $\begin{array}{c}-0.665^{\star \star \star} \\
{[0.105]}\end{array}$ & $\begin{array}{c}-0.595^{\star \star \star} \\
{[0.140]}\end{array}$ \\
\hline house & & $\begin{array}{c}-0.053 \\
{[0.163]}\end{array}$ & $\begin{array}{c}0.418^{* * *} \\
{[0.130]}\end{array}$ & $\begin{array}{c}0.563^{* * *} \\
{[0.180]}\end{array}$ \\
\hline lexpc & & $\begin{array}{c}0.455^{\star \star *} \\
{[0.081]}\end{array}$ & $\begin{array}{c}0.564^{\star * *} \\
{[0.078]}\end{array}$ & $\begin{array}{c}0.130^{*} \\
{[0.078]}\end{array}$ \\
\hline Constant & & $\begin{array}{c}-15.631^{* * *} \\
{[3.972]}\end{array}$ & $\begin{array}{c}-26.572^{\star \star \star} \\
{[2.679]}\end{array}$ & $\begin{array}{c}-21.911^{* * *} \\
{[3.441]}\end{array}$ \\
\hline Pseudo R2 & & 0.0 & & \\
\hline Observations & & 95 & & \\
\hline Prefecture dummies & & $Y_{\epsilon}$ & & \\
\hline
\end{tabular}


Table 5: Not work, nonregular work, regular work, or self-employed? (Female, multinomial logit)

\begin{tabular}{|c|c|c|c|c|c|c|c|c|}
\hline \multirow[b]{2}{*}{ VARIABLES } & \multirow{2}{*}{$\begin{array}{c}\text { (1) } \\
\text { Not work } \\
\text { (default } \\
\text { category) } \\
\end{array}$} & \multicolumn{2}{|c|}{$\begin{array}{lr}(2) & (3) \\
\text { Multinomial logit }\end{array}$} & \multirow{2}{*}{$\begin{array}{c}\text { (4) } \\
\text { Self- } \\
\text { employed }\end{array}$} & \multicolumn{4}{|c|}{ 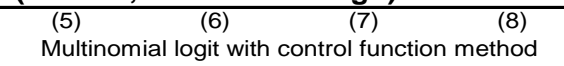 } \\
\hline & & $\begin{array}{l}\text { Non-regular } \\
\text { worker }\end{array}$ & $\begin{array}{l}\text { Regular } \\
\text { worker }\end{array}$ & & $\begin{array}{c}\text { Not work } \\
\text { (default } \\
\text { category) }\end{array}$ & $\begin{array}{l}\text { Non-regular } \\
\text { worker }\end{array}$ & $\begin{array}{l}\text { Regular } \\
\text { worker }\end{array}$ & $\begin{array}{c}\text { Self- } \\
\text { employed }\end{array}$ \\
\hline \multicolumn{9}{|l|}{ Marginal effect } \\
\hline Main caregiver dummy & $\begin{array}{l}0.088^{\star \star \star} \\
{[0.013]}\end{array}$ & $\begin{array}{l}-0.022 \\
{[0.015]}\end{array}$ & $\begin{array}{c}-0.088^{\star \star \star \star} \\
{[0.014]}\end{array}$ & $\begin{array}{l}0.023^{\star *} \\
{[0.011]}\end{array}$ & $\begin{array}{l}0.276^{\star \star \star} \\
{[0.047]}\end{array}$ & $\begin{array}{l}-0.067 \\
{[0.054]}\end{array}$ & $\begin{array}{c}-0.191^{\star \star \star} \\
{[0.050]}\end{array}$ & $\begin{array}{l}-0.017 \\
{[0.040]}\end{array}$ \\
\hline LTCI eligibility dummy & $\begin{array}{c}0.002 \\
{[0.016]}\end{array}$ & $\begin{array}{l}-0.007 \\
{[0.017]}\end{array}$ & $\begin{array}{l}-0.001 \\
{[0.017]}\end{array}$ & $\begin{array}{c}0.003 \\
{[0.013]}\end{array}$ & $\begin{array}{l}-0.004 \\
{[0.015]}\end{array}$ & $\begin{array}{l}-0.006 \\
{[0.020]}\end{array}$ & $\begin{array}{c}0.005 \\
{[0.018]}\end{array}$ & $\begin{array}{c}0.004 \\
{[0.012]}\end{array}$ \\
\hline \multicolumn{9}{|l|}{ Estimation results } \\
\hline Main caregiver dummy & & $\begin{array}{l}-0.468^{\star \star \star} \\
{[0.093]}\end{array}$ & $\begin{array}{l}-0.738^{\star \star *} \\
{[0.086]}\end{array}$ & $\begin{array}{l}-0.215^{*} \\
{[0.118]}\end{array}$ & & $\begin{array}{c}-1.444^{\star \star *} \\
{[0.318]}\end{array}$ & $\begin{array}{l}-1.970^{\star \star \star} \\
{[0.334]}\end{array}$ & $\begin{array}{c}-1.318^{\star \star \star} \\
{[0.400]}\end{array}$ \\
\hline LTCI eligibility dummy & & $\begin{array}{l}-0.035 \\
0.105]\end{array}$ & $\begin{array}{l}-0.010 \\
{[0.107]}\end{array}$ & $\begin{array}{c}0.013 \\
{[0.146]}\end{array}$ & & $\begin{array}{l}0.001 \\
{[0.107]}\end{array}$ & $\begin{array}{c}0.040 \\
0.111]\end{array}$ & $\begin{array}{c}0.053 \\
{[0.116]}\end{array}$ \\
\hline age & & $\begin{array}{l}0.585^{\star \star \star} \\
10.0941\end{array}$ & $\begin{array}{l}0.869^{\star \star \star} \\
0.1011\end{array}$ & $\begin{array}{l}0.385^{\star \star \star} \\
{[0.1031}\end{array}$ & & $\begin{array}{l}0.557^{\star \star \star \star} \\
{[0.099]}\end{array}$ & $\begin{array}{l}0.832^{\star \star \star} \\
{[0.108]}\end{array}$ & $\begin{array}{l}0.354^{\star \star \star \star} \\
{[0.125]}\end{array}$ \\
\hline age squared & & $\begin{array}{l}-0.006^{\star \star \star} \\
{[0.001]}\end{array}$ & $\begin{array}{l}-0.009^{\star \star \star} \\
{[0.001]}\end{array}$ & $\begin{array}{l}-0.004^{\star \star \star} \\
{[0.001]}\end{array}$ & & $\begin{array}{l}-0.006^{\star \star *} \\
{[0.001]}\end{array}$ & $\begin{array}{l}-0.009^{\star \star \star} \\
{[0.001]}\end{array}$ & $\begin{array}{l}-0.003^{\star \star \star} \\
{[0.001]}\end{array}$ \\
\hline marriage & & $\begin{array}{c}0.096 \\
{[0.093]}\end{array}$ & $\begin{array}{l}-0.582^{\star \star \star} \\
{[0.091]}\end{array}$ & $\begin{array}{l}0.363^{\star \star} \\
{[0.150]}\end{array}$ & & $\begin{array}{c}0.090 \\
{[0.081]}\end{array}$ & $\begin{array}{l}-0.588^{\star \star \star} \\
{[0.081]}\end{array}$ & $\begin{array}{l}0.355^{\star \star \star} \\
{[0.118]}\end{array}$ \\
\hline kid & & $\begin{array}{l}0.267^{\star \star \star} \\
{[0.090]}\end{array}$ & $\begin{array}{l}-0.006 \\
{[0.077]}\end{array}$ & $\begin{array}{c}0.048 \\
{[0.106]}\end{array}$ & & $\begin{array}{l}0.274^{\star \star \star} \\
{[0.078]}\end{array}$ & $\begin{array}{c}0.004 \\
{[0.082]}\end{array}$ & $\begin{array}{c}0.057 \\
{[0.099]}\end{array}$ \\
\hline edu2 & & $\begin{array}{c}0.165 \\
{[0.137]}\end{array}$ & $\begin{array}{c}0.350^{\star} \\
{[0.179]}\end{array}$ & $\begin{array}{l}-0.058 \\
{[0.156]}\end{array}$ & & $\begin{array}{c}0.164 \\
{[0.133]}\end{array}$ & $\begin{array}{l}0.349^{\star \star} \\
{[0.159]}\end{array}$ & $\begin{array}{l}-0.060 \\
{[0.156]}\end{array}$ \\
\hline edu3 & & $\begin{array}{c}0.095 \\
{[0.149]}\end{array}$ & $\begin{array}{l}0.657^{\star \star \star \star} \\
{[0.194]}\end{array}$ & $\begin{array}{c}0.021 \\
{[0.152]}\end{array}$ & & $\begin{array}{c}0.086 \\
{[0.142]}\end{array}$ & $\begin{array}{l}0.646^{\star \star \star} \\
{[0.168]}\end{array}$ & $\begin{array}{c}0.009 \\
{[0.164]}\end{array}$ \\
\hline edu4 & & $\begin{array}{l}-0.042 \\
{[0.218]}\end{array}$ & $\begin{array}{l}0.966^{\star \star \star} \\
{[0.219]}\end{array}$ & $\begin{array}{c}0.326 \\
{[0.202]}\end{array}$ & & $\begin{array}{l}-0.018 \\
{[0.184]}\end{array}$ & $\begin{array}{l}0.996^{* * *} \\
{[0.191]}\end{array}$ & $\begin{array}{l}0.351^{*} \\
{[0.202]}\end{array}$ \\
\hline edu9 & & -0.118 & -0.001 & -0.182 & & -0.105 & 0.017 & -0.169 \\
\hline & & [0.162] & {$[0.203]$} & {$[0.169]$} & & {$[0.182]$} & {$[0.200]$} & {$[0.208]$} \\
\hline health & & $-0.125^{\star}$ & -0.022 & -0.065 & & -0.000 & 0.136 & 0.075 \\
\hline & & {$[0.067]$} & [0.082] & [0.091] & & [0.089] & [0.089] & {$[0.098]$} \\
\hline house & & 0.047 & 0.079 & 0.144 & & 0.025 & 0.052 & 0.118 \\
\hline & & {$[0.135]$} & {$[0.141]$} & {$[0.195]$} & & {$[0.144]$} & {$[0.141]$} & {$[0.193]$} \\
\hline lexpc & & 0.028 & $0.118^{\star \star}$ & $-0.147^{\star \star}$ & & 0.039 & $0.132^{\star \star}$ & $-0.134^{*}$ \\
\hline resid & & [0.049] & {$[0.055]$} & {$[0.069]$} & & $\begin{array}{l}{[0.058]} \\
1.018^{\star \star \star} \\
{[0.320]}\end{array}$ & $\begin{array}{l}{[0.060]} \\
1.284^{\star \star \star} \\
{[0.331]}\end{array}$ & $\begin{array}{l}{[0.072]} \\
1.150^{\star \star \star *} \\
{[0.405]}\end{array}$ \\
\hline Constant & & $\begin{array}{c}-13.477^{* * *} \\
{[2.329]}\end{array}$ & $\begin{array}{c}-20.532^{* * *} \\
{[2.511]}\end{array}$ & $\begin{array}{c}-10.012^{\star \star \star} \\
{[2.615]}\end{array}$ & & $\begin{array}{c}-12.885^{\star \star \star} \\
{[2.470]}\end{array}$ & $\begin{array}{c}-19.766^{\star \star \star} \\
{[2.683]}\end{array}$ & $\begin{array}{l}-9.342^{\star \star \star} \\
{[3.165]}\end{array}$ \\
\hline Pseudo $R$ & & & 50 & & & 0.0 & & \\
\hline Observations & & & & & & 8,9 & & \\
\hline Prefecture dummies & & & & & & & & \\
\hline
\end{tabular}

Clustered standard errors at prefecture level (multinomial logit) and bootstrapped standard errors (multinomial logit with control function method) in brackets

${ }^{* * \star} P<0.01,{ }^{\star \star} P<0.05,{ }^{*} P<0.1$ 
Table 6: Working hours (Male, OLS and IV)

\begin{tabular}{|c|c|c|c|c|}
\hline VARIABLES & $\begin{array}{c}(1) \\
\text { OLS }\end{array}$ & $\begin{array}{c}(2) \\
\text { OLS }\end{array}$ & $\begin{array}{l}\text { (3) } \\
\text { IV }\end{array}$ & $\begin{array}{l}\text { (4) } \\
\text { IV }\end{array}$ \\
\hline Main caregiver dummy & $\begin{array}{c}-1.367^{* *} \\
{[0.614]}\end{array}$ & $\begin{array}{c}-1.783^{* *} \\
{[0.719]}\end{array}$ & $\begin{array}{l}-0.589 \\
{[3.382]}\end{array}$ & $\begin{array}{l}-2.766 \\
{[6.060]}\end{array}$ \\
\hline LTCI eligibility dummy & & $\begin{array}{l}0.869^{*} \\
{[0.509]}\end{array}$ & & $\begin{array}{c}1.103 \\
{[1.479]}\end{array}$ \\
\hline age & $\begin{array}{l}0.914^{*} \\
{[0.490]}\end{array}$ & $\begin{array}{l}0.947^{*} \\
{[0.486]}\end{array}$ & $\begin{array}{l}0.903^{*} \\
{[0.478]}\end{array}$ & $\begin{array}{l}0.969^{\star *} \\
{[0.474]}\end{array}$ \\
\hline age squared & $\begin{array}{l}-0.012^{* *} \\
{[0.005]}\end{array}$ & $\begin{array}{c}-0.013^{* *} \\
{[0.005]}\end{array}$ & $\begin{array}{l}-0.012^{* * *} \\
{[0.005]}\end{array}$ & $\begin{array}{c}-0.013^{* * *} \\
{[0.005]}\end{array}$ \\
\hline marriage & $\begin{array}{c}3.242^{* * *} \\
{[0.459]}\end{array}$ & $\begin{array}{c}3.164^{\star * *} \\
{[0.460]}\end{array}$ & $\begin{array}{c}3.323^{* * *} \\
{[0.554]}\end{array}$ & $\begin{array}{c}3.053^{* * *} \\
{[0.809]}\end{array}$ \\
\hline kid & $\begin{array}{c}0.294 \\
{[0.355]}\end{array}$ & $\begin{array}{c}0.304 \\
{[0.354]}\end{array}$ & $\begin{array}{c}0.278 \\
{[0.362]}\end{array}$ & $\begin{array}{c}0.325 \\
{[0.382]}\end{array}$ \\
\hline edu2 & $\begin{array}{l}1.920^{* * *} \\
{[0.658]}\end{array}$ & $\begin{array}{l}1.922^{\star * *} \\
{[0.661]}\end{array}$ & $\begin{array}{l}1.932^{\star \star \star \star} \\
{[0.662]}\end{array}$ & $\begin{array}{c}1.909^{\star \star \star} \\
{[0.663]}\end{array}$ \\
\hline edu3 & $\begin{array}{c}2.433^{\star * *} \\
{[0.821]}\end{array}$ & $\begin{array}{c}2.438^{\star * *} \\
{[0.821]}\end{array}$ & $\begin{array}{c}2.432^{\star \star *} \\
{[0.805]}\end{array}$ & $\begin{array}{c}2.441^{* * *} \\
{[0.811]}\end{array}$ \\
\hline edu4 & $\begin{array}{c}2.970^{* * *} \\
{[0.743]}\end{array}$ & $\begin{array}{c}2.970^{* * *} \\
{[0.747]}\end{array}$ & $\begin{array}{c}2.975^{\star * *} \\
{[0.736]}\end{array}$ & $\begin{array}{c}2.965^{\star * *} \\
{[0.742]}\end{array}$ \\
\hline edu9 & $\begin{array}{l}2.134^{* *} \\
{[1.010]}\end{array}$ & $\begin{array}{l}2.121^{\star *} \\
{[1.010]}\end{array}$ & $\begin{array}{l}2.149^{* *} \\
{[1.006]}\end{array}$ & $\begin{array}{l}2.101^{\star *} \\
{[1.010]}\end{array}$ \\
\hline health & $\begin{array}{c}0.947^{* * *} \\
{[0.346]}\end{array}$ & $\begin{array}{l}0.915^{\star *} \\
{[0.343]}\end{array}$ & $\begin{array}{l}0.910^{* *} \\
{[0.384]}\end{array}$ & $\begin{array}{l}0.948^{\star *} \\
{[0.389]}\end{array}$ \\
\hline house & $\begin{array}{c}0.124 \\
{[0.596]}\end{array}$ & $\begin{array}{c}0.145 \\
{[0.591]}\end{array}$ & $\begin{array}{c}0.136 \\
{[0.600]}\end{array}$ & $\begin{array}{c}0.138 \\
{[0.588]}\end{array}$ \\
\hline lexpc & $\begin{array}{c}0.076 \\
{[0.252]}\end{array}$ & $\begin{array}{c}0.067 \\
{[0.254]}\end{array}$ & $\begin{array}{c}0.067 \\
{[0.252]}\end{array}$ & $\begin{array}{c}0.075 \\
{[0.256]}\end{array}$ \\
\hline experience & $\begin{array}{c}0.088^{* * *} \\
{[0.016]}\end{array}$ & $\begin{array}{l}0.087^{* \star *} \\
{[0.016]}\end{array}$ & $\begin{array}{c}0.088^{* * *} \\
{[0.016]}\end{array}$ & $\begin{array}{c}0.087^{* * *} \\
{[0.016]}\end{array}$ \\
\hline public & $\begin{array}{l}-3.802^{* * *} \\
{[0.503]}\end{array}$ & $\begin{array}{c}-3.787^{* * *} \\
{[0.501]}\end{array}$ & $\begin{array}{l}-3.807^{* * *} \\
{[0.500]}\end{array}$ & $\begin{array}{c}-3.777^{* * *} \\
{[0.505]}\end{array}$ \\
\hline fsize2 & $\begin{array}{c}-1.794^{* * *} \\
{[0.420]}\end{array}$ & $\begin{array}{c}-1.806^{* * *} \\
{[0.419]}\end{array}$ & $\begin{array}{c}-1.798^{* * *} \\
{[0.410]}\end{array}$ & $\begin{array}{c}-1.804^{* * *} \\
{[0.412]}\end{array}$ \\
\hline fsize3 & $\begin{array}{c}-2.889^{* * *} \\
{[0.361]}\end{array}$ & $\begin{array}{c}-2.903^{\star * *} \\
{[0.359]}\end{array}$ & $\begin{array}{c}-2.891^{* * *} \\
{[0.357]}\end{array}$ & $\begin{array}{c}-2.905^{\star * *} \\
{[0.352]}\end{array}$ \\
\hline Constant & $\begin{array}{l}29.667^{* *} \\
{[12.763]}\end{array}$ & $\begin{array}{l}28.940^{* *} \\
{[12.667]}\end{array}$ & & \\
\hline $\begin{array}{l}\text { Observations } \\
\text { R-squared }\end{array}$ & $\begin{array}{l}8,309 \\
0.050\end{array}$ & $\begin{array}{l}8,309 \\
0.050\end{array}$ & 8,309 & 8,309 \\
\hline F-value of 1 st stage & & & 31.86 & 46.38 \\
\hline Prefecture dummies & Yes & Yes & Yes & Yes \\
\hline
\end{tabular}


Table 7: Working hours (Female, OLS and IV)

\begin{tabular}{|c|c|c|c|c|}
\hline VARIABLES & $\begin{array}{l}1) \\
\text { OLS }\end{array}$ & $\begin{array}{l}(2) \\
\text { OLS }\end{array}$ & $\begin{array}{l}\text { (3) } \\
\text { IV }\end{array}$ & $\begin{array}{l}(4) \\
\text { IV }\end{array}$ \\
\hline Main caregiver dummy & $\begin{array}{c}-2.384^{* * *} \\
{[0.514]}\end{array}$ & $\begin{array}{c}-2.141^{* * *} \\
{[0.616]}\end{array}$ & $\begin{array}{c}-7.615^{* * *} \\
{[1.887]}\end{array}$ & $\begin{array}{c}-13.034^{* * *} \\
{[4.948]}\end{array}$ \\
\hline LTCI eligibility dummy & & $\begin{array}{l}-0.397 \\
{[0.701]}\end{array}$ & & $\begin{array}{l}6.867^{\star \star} \\
{[3.359]}\end{array}$ \\
\hline age & $\begin{array}{c}0.600 \\
{[0.526]}\end{array}$ & $\begin{array}{c}0.590 \\
{[0.525]}\end{array}$ & $\begin{array}{c}0.387 \\
{[0.502]}\end{array}$ & $\begin{array}{c}0.513 \\
{[0.519]}\end{array}$ \\
\hline age squared & $\begin{array}{l}-0.009 \\
{[0.005]}\end{array}$ & $\begin{array}{l}-0.009 \\
{[0.005]}\end{array}$ & $\begin{array}{l}-0.006 \\
{[0.005]}\end{array}$ & $\begin{array}{l}-0.007 \\
{[0.005]}\end{array}$ \\
\hline marriage & $\begin{array}{c}-2.708^{* * *} \\
{[0.599]}\end{array}$ & $\begin{array}{c}-2.685^{\star * *} \\
{[0.602]}\end{array}$ & $\begin{array}{c}-2.787^{\star * *} \\
{[0.587]}\end{array}$ & $\begin{array}{c}-3.209^{* * *} \\
{[0.660]}\end{array}$ \\
\hline kid & $\begin{array}{c}-2.189^{* * *} \\
{[0.580]}\end{array}$ & $\begin{array}{c}-2.188^{\star * *} \\
{[0.579]}\end{array}$ & $\begin{array}{c}-2.135^{\star * *} \\
{[0.589]}\end{array}$ & $\begin{array}{c}-2.130^{* * *} \\
{[0.612]}\end{array}$ \\
\hline edu2 & $\begin{array}{c}1.351 \\
{[0.908]}\end{array}$ & $\begin{array}{c}1.342 \\
{[0.903]}\end{array}$ & $\begin{array}{c}1.180 \\
{[0.883]}\end{array}$ & $\begin{array}{c}1.311 \\
{[0.934]}\end{array}$ \\
\hline edu3 & $\begin{array}{c}1.499 \\
{[1.015]}\end{array}$ & $\begin{array}{c}1.489 \\
{[1.009]}\end{array}$ & $\begin{array}{c}1.340 \\
{[0.995]}\end{array}$ & $\begin{array}{c}1.482 \\
{[1.035]}\end{array}$ \\
\hline edu4 & $\begin{array}{c}4.173^{\star * *} \\
{[1.401]}\end{array}$ & $\begin{array}{c}4.167^{* * *} \\
{[1.394]}\end{array}$ & $\begin{array}{c}4.276^{\star * *} \\
{[1.376]}\end{array}$ & $\begin{array}{c}4.419^{* * *} \\
{[1.442]}\end{array}$ \\
\hline edu9 & $\begin{array}{c}1.442 \\
{[1.106]}\end{array}$ & $\begin{array}{c}1.433 \\
{[1.103]}\end{array}$ & $\begin{array}{c}1.557 \\
{[1.093]}\end{array}$ & $\begin{array}{c}1.742 \\
{[1.142]}\end{array}$ \\
\hline health & $\begin{array}{l}1.153^{\star *} \\
{[0.456]}\end{array}$ & $\begin{array}{l}1.164^{* *} \\
{[0.459]}\end{array}$ & $\begin{array}{l}1.789^{* * *} \\
{[0.539]}\end{array}$ & $\begin{array}{l}1.749^{* * *} \\
{[0.595]}\end{array}$ \\
\hline house & $\begin{array}{c}-2.174^{* *} \\
{[0.824]}\end{array}$ & $\begin{array}{c}-2.173^{\star *} \\
{[0.824]}\end{array}$ & $\begin{array}{c}-2.219^{* * *} \\
{[0.817]}\end{array}$ & $\begin{array}{c}-2.243^{\star \star *} \\
{[0.828]}\end{array}$ \\
\hline lexpc & $\begin{array}{c}-1.465^{\star * *} \\
{[0.311]}\end{array}$ & $\begin{array}{c}-1.463^{* * *} \\
{[0.311]}\end{array}$ & $\begin{array}{c}-1.397^{* * *} \\
{[0.309]}\end{array}$ & $\begin{array}{c}-1.409^{* * *} \\
{[0.310]}\end{array}$ \\
\hline experience & $\begin{array}{c}0.406^{\star * *} \\
{[0.016]}\end{array}$ & $\begin{array}{c}0.407^{\star * *} \\
{[0.016]}\end{array}$ & $\begin{array}{c}0.404^{\star * *} \\
{[0.015]}\end{array}$ & $\begin{array}{c}0.399^{* * *} \\
{[0.016]}\end{array}$ \\
\hline public & $\begin{array}{l}1.610^{* *} \\
{[0.632]}\end{array}$ & $\begin{array}{l}1.608^{* *} \\
{[0.632]}\end{array}$ & $\begin{array}{l}1.323^{\star *} \\
{[0.646]}\end{array}$ & $\begin{array}{l}1.287^{\star} \\
{[0.679]}\end{array}$ \\
\hline fsize2 & $\begin{array}{c}0.372 \\
{[0.395]}\end{array}$ & $\begin{array}{c}0.373 \\
{[0.396]}\end{array}$ & $\begin{array}{c}0.254 \\
{[0.401]}\end{array}$ & $\begin{array}{c}0.209 \\
{[0.396]}\end{array}$ \\
\hline fsize3 & $\begin{array}{l}-0.581 \\
{[0.484]}\end{array}$ & $\begin{array}{l}-0.580 \\
{[0.484]}\end{array}$ & $\begin{array}{l}-0.613 \\
{[0.470]}\end{array}$ & $\begin{array}{l}-0.640 \\
{[0.476]}\end{array}$ \\
\hline Constant & $\begin{array}{l}27.938^{* *} \\
{[12.856]}\end{array}$ & $\begin{array}{l}28.155^{* *} \\
{[12.828]}\end{array}$ & & \\
\hline Obse & 6,723 & 6,723 & 6,723 & 6,723 \\
\hline R-squared & 0.151 & 0.151 & & \\
\hline F-value of 1 st stage & & & 46.93 & 302.65 \\
\hline Prefecture dummies & Yes & Yes & Yes & Yes \\
\hline
\end{tabular}

